\title{
Saving us from the Digital Dark Age: the Austrian perspective
}

\author{
Martina Trognitz
}

\section{Summary}

In Austria, archaeological research and excavation practice is shaped by a legislative framework and institutional actors. Besides the institutions, the role of private archaeological contractors has grown in the last decade and recently non-commercial associations have been founded. According to the Austrian Monument Protection Act, the Federal Monuments Authority issues permits for any archaeological excavation or survey activity. Documentation and preservation of physical material are regulated by the Monument Protection Act as well as by dedicated guidelines published by the Federal Monuments Authority. With the recent increased use of digital methods, the importance of preserving and disseminating digital data has risen. Although the Austrian government pursues a digitisation agenda including the promotion of Open Science, the availability of repositories suitable for long-term preservation of digital data does not meet the requirements arising from the ever-increasing amount of data.

\section{Introduction}

The Republic of Austria is located in the southern part of Central Europe at the eastern end of the Alps. This landlocked country, with a population of roughly 8.9 million, is a federal republic with nine states (Bundesländer), including the capital, Vienna. Archaeological remains range from prehistoric and Roman to medieval and modern times. Four of the ten UNESCO World Heritage Sites within Austria are of archaeological importance (Figure 1).

This contribution summarises current archaeological research and excavation practice within Austria, and the legislative framework, its actors, and the handling of digital data. In particular, the issues surrounding data storage and dissemination are addressed. 


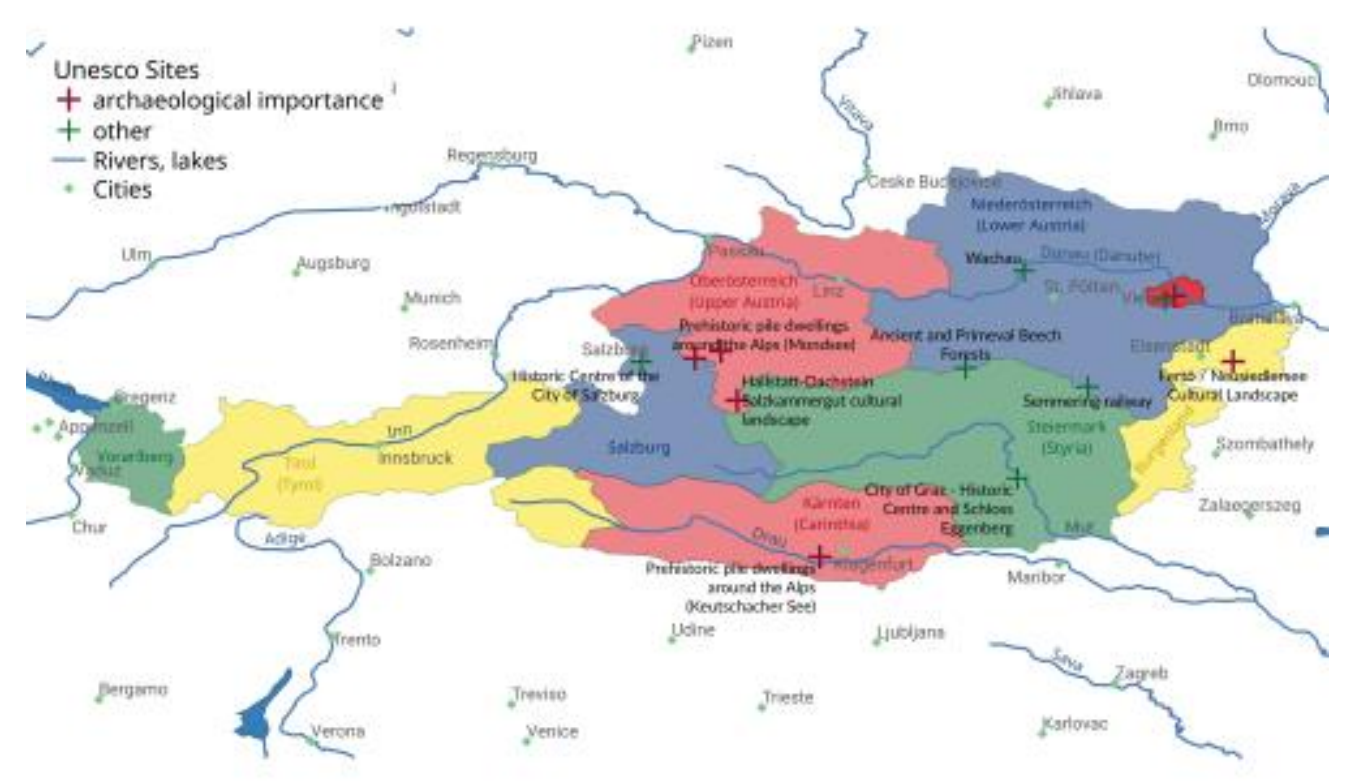

Figure 1: The Republic of Austria with its nine states hosts ten UNESCO World Heritage Sites, of which four are of archaeological relevance (red plus); the Historic Centre of Vienna, the Fertö / Neusiedlersee Cultural Landscape, the Hallstatt-Dachstein / Salzkammergut Cultural Landscape, and the Prehistoric Pile Dwellings (considered as one but spread around three lakes).

\section{Archaeological Practice in Austria}

An overview of archaeological practice in Austria as of 2003 is given in Friesinger and Titscher (2004). It is still valid today in its main aspects, but a survey summarised by Karl and Möller (2014) provides an updated snapshot of archaeological practice. From these reports, it is clear that archaeological research and excavations in Austria are guided primarily by current legislation and the institutional actors involved.

\subsection{Legislation}

The Denkmalschutzgesetz (DMSG, Monument Protection Act) in its current revision of 2013-06-17 governs all issues concerning the management of Austrian material cultural heritage. The formal title is 'Bundesgesetz betreffend den Schutz von Denkmalen wegen ihrer geschichtlichen, künstlerischen oder sonstigen kulturellen Bedeutung' (Federal Act on the Protection of Monuments due to their historic, artistic or other cultural significance).

DMSG \&167; 11 regulates excavation obligations and \&167; 11,1 explicitly states that any activity with the purpose 'of discovering and examining movable and immovable monuments beneath the surface of the earth or water' requires a permit (DMSG \&167; 11,1). This is issued by the Bundesdenkmalamt Österreich (BDA, Federal Monuments 
Authority Austria) and is only granted to persons with a relevant university degree. Additionally, $\S 11,4$ states that the BDA has to be provided with regular comprehensive reports of the activities as well as documentation such as drawings, plans, and photographs. The extent of the documentation should conform to scientific principles.

In 2010 the BDA introduced Guidelines for Archaeological Interventions [PDF], which provide definitions and further details including accepted file formats and a folder structure for the reports and documentation. The guidelines help to establish minimum standards and are currently available in their fifth revision (BDA Guidelines 2018). A set of document templates complements the guidelines.

The DMSG provides a legal framework for archaeological fieldwork and resulting documentation in Austria only. Any data collected in the course of Austrian excavations abroad are not affected and its management is subject to the respective projects or policies of the hosting institutions.

Two European treaties also influence how archaeological work is carried out: the Valletta Treaty (Treaty No. 143) and the Faro Treaty (Treaty No. 199). The Valletta Treaty aims to integrate archaeological conservation and investigation into regional planning policies, including the cooperation of archaeologists and urban developers. Guidelines for funding, execution of archaeological work, and publication thereof are also included. Another goal is the strengthening of international cooperation, including the exchange of scientific information, technologies, and expertise. The Faro Treaty strengthens the citizen's rights regarding access to, benefitting from, and participation in cultural heritage and the sustainable development of digital technologies is also addressed.

\subsection{Actors}

The Bundesdenkmalamt Österreich (BDA, Federal Monuments Authority Austria) is the authority that fulfils the responsibilities of the DMSG. It has a department for archaeology and for each state a staff member of the BDA is available for consultation, applications and collecting reports. At the state level, the state museums (e.g. Salzburg Museum or Landesmuseum Burgenland) collect, preserve, document, scientifically examine, and disseminate regional archaeological finds. There are also dedicated local museums for prominent sites (e.g. Museum Hallstatt or Carnuntum). The federal museums (e.g. KHM-Museumsverband or Naturhistorisches Museum) fulfil their mandate at a national level.

Four universities, located in Graz, Innsbruck, Salzburg and Vienna, offer archaeologyrelated degrees and are involved in archaeological research in Austria and abroad. Additionally, the Austrian Archaeological Institute of the Austrian Academy of Sciences and the Ludwig Boltzmann Institute for Archaeological Prospection and Virtual Archaeology ( $\mathrm{LBI}$ ArchPro) also participate in national and international archaeological interventions and surveys.

The aforementioned actors are represented in the Archaeological Council (Archäologischer Rat) established in 2016 at the Austrian Academy of Sciences. The council aims to develop joint strategies and acts as a central coordinating link between all actors. 
The role of private archaeological contractors (for a list see AS-Archäologie) has grown since 2008, after the BDA withdrew from directly awarding contracts for archaeological interventions (Karl and Möller 2014, 24). Furthermore, non-commercial associations have recently formed to enable citizens to participate in archaeological activities (Peter 2019).

\subsection{Digital practice}

When it comes to preserving and disseminating digital data, Austrian archaeologists seem to be late bloomers. In 2003, digital methods and data were not on the agenda of most Austrian archaeologists (Friesinger and Titscher 2004), even as an aspiration for the future, as also stressed by F. Steininger (cited in Friesinger and Titscher 2004, 624).

Ten years later in 2013 the situation was much the same (Aspöck 2019), although the use of digital methods has increased. Indications of this are the founding of the LBI ArchPro in 2010, the establishment of the group Digital Archaeology at the Institute for Oriental and European Archaeology (OREA) in 2015 (Horejs and OREA team 2016, 21), which was reorganised into the DIGital Documentation Lab in 2018 (Horejs 2018, 93), and the installation of the working group 'Digging Digital' at the Austrian Archaeological Institute (ÖAI) in 2017 (ÖAI 2017, 80). Furthermore, the three archaeological institutes of the Austrian Academy of Sciences (IKAnt, ÖAl and OREA) were organised into the Cluster Archaeology and Classics (CLAC) with a dedicated section for digital methods (eCLAC), before they all merged into the new Austrian Archaeological Institute in 2021. This new institute now has a unit Digital Archaeology and Classics (DAC) to pursue the digital agenda of the ÖAI.

How researchers in Austria handle their research data is summarised by Bauer et al. $(\underline{2015})$ in the results of a survey on research data management conducted in 2015. Roughly a quarter of the respondents were humanities researchers (Bauer et al. 2015, 21). Hence, it can be assumed that it also reflects archaeological practice. Main findings of the survey were that nearly all participants produced digital data of some kind (Bauer et al. 2015, 65), that more than a third had already experienced data loss (Bauer et al. 2015, 7, 10), and that only about a third (or even less if participants from the Technical University and the Economics University are excluded) store their data in an institutional repository (Bauer et al. 2015, 28). Hence, Bauer et al. $(\underline{2015}, 11)$ recommended the creation of a data management and preservation infrastructure in Austria, the adoption of standards and best practice policies, and the provision of data management support for researchers.

A study commissioned by the Austrian Bundesministerium für Bildung, Wissenschaft und Forschung (BMBWF, Austrian Federal Ministry of Education, Science and Research) explored the digital humanities landscape in Austria in 2019 (Mayer 2019). It shows that archaeology is among the central subjects in digital humanities research in Austria (Mayer 2019, 63) and stands out with numerous teaching programmes (Mayer 2019, 75). Recommendations of the study included sustainable funding of infrastructures for data preservation and the reinforcement of cooperation, a federation of data, and networking. 


\section{Preserving Physical Material}

Archaeological finds are stored and preserved in dedicated facilities at individual museums, or at the archaeology centre in the former Carthusian monastery at Mauerbach. However, capacity is limited and some warehouses have already reached their limit (Karl and Möller 2014, 21; Karl 2015, 219; Breibert 2019, 27-29; Volgger 2020, 14-15).

The workspaces at Mauerbach provide modern equipment for use by BDA staff as well as external project partners for conservation and restoration of finds (Blesl et al. $\underline{2015}$, 3). A set of standards and guidelines published by the BDA (BDA Standards) complements the measures for the conservation of finds.

The depot in the former Carthusian monastery at Mauerbach has been in use since 2012. It functions as a store for finds and also holds the archive with all documentation reports from archaeological interventions in Austria from 2012 onwards (Blesl et al. 2015; see Archäologiezentrum Mauerbach). On-site access to the archived material is only possible for researchers and specialists (Blesl et al. 2015). Parts of the archived documentation from earlier activities are still kept in the headquarters of the BDA's archaeological department in the Vienna Hofburg (Blesl et al. 2015). The inventory of the BDA archive is not available online, although a federated infrastructure for digital archive inventories exists with ArchivNet, which was derived from the ICARUS network.

In addition to keeping the inventory of finds, according to an amendment from 1990 in DMSG \&167; 11, 7 (Hofer 2011, 13), the BDA also has to summarise findings of scientific relevance in an annual publication within a period of five years. This is published in the series Fundberichte aus Österreich (BDA FÖ), with 57 volumes as of 2020 and over 800 articles and 25,000 excavation reports in 2011 (Hofer 2011, 13). From 2011 onwards the printed volume is accompanied by an extended ebook. Neither the printed nor the digital version of the Fundberichte are available as Open Access.

\section{Preserving Digital Documentation}

The preservation of digital documentation is not prescribed in the DMSG or any other law, but the Guidelines for Archaeological Interventions of the BDA specify that digital documentation has to be submitted on a storage medium that will remain with the BDA (BDA Guidelines $\underline{2018}, 36$ ). The folder structure and file formats are also specified (BDA Guidelines 2018, 36-43).

The Fonds zur Förderung der wissenschaftlichen Forschung (FWF, Austrian Science Fund), a key funding body for scientific research in Austria, has an Open Access Policy that pertains to publications as well as research data. Consequently, projects fully or partially funded by the FWF have to comply with this policy, which mandates open access and the long-term preservation of research data for projects approved from 1 January 2019 onwards.

Within the framework of Austria's recent digitisation agenda, efforts are being made to promote Open Science in research, especially Open Access. Initiatives include the Open Science Network Austria (OANA) and participation in OpenAIRE and the European 
Open Science Cloud (EOSC). The BMBWF presents Open Science as a key

topic (BMBWF Open Science) and includes it in the target and performance agreements with the universities. The ministry is also aiming to develop an Open Data strategy

(Digital Roadmap Austria 2016, 24).

\section{Availability of Repositories for Digital Documentation}

While the principle of Open Access publishing is becoming standard practice and the number of repositories is increasing, the principles of Open Science in general, and Open Data in particular, still require awareness-building activities, including the establishment of additional suitable digital archives for the long-term preservation of data. The development and availability of such archives lag behind the ever-increasing amount of data being produced.

\subsection{Data repositories in Austria}

The last ten years have seen an increase in digital repositories in Austria. OpenDOAR serves as a rough indicator for this development: in 2010 there were ten, in 2015 there were 22, in 2018 there were 30 (Bauer and Ferus 2018, 78), and by 2021 a total of 44 Austrian repositories were listed on OpenDOAR. This rise in the number of repositories can be directly linked to dedicated funding and digitisation agendas, e.g. e-Infrastructures Austria from 2014 to 2016 (Bauer and Ferus 2018, 74).

However, the majority of these 44 repositories are intended for publications and only accept content types such as journal articles, theses or reports. Only 14 repositories remain when filtering for those that accept 'Datasets' or 'Other Special Item Types'. This number is further reduced to eight by only counting those with subjects matching archaeological research like 'Multidisciplinary', 'Arts and Humanities General' or 'Arts and Humanities General > History and Archaeology'. A closer look into the repositories leaves four, maybe even only three, repositories suitable for archaeological research data: ARCHE, GAMS, University of Vienna PHAIDRA, and maybe also PHAIDRA @ FH St Pölten. The same list of repositories can also be found on re3data.org with a similar filtering process. When looking for a trustworthy repository, i.e. a service holding an internationally recognised accreditation, only two repositories with the CoreTrustSeal remain: ARCHE and GAMS. All four repositories are described below.

\subsection{Other data hosting and dissemination means}

OpenDOAR and re3data.org provide an easy way to find repositories that may be useful for an area of research, which is a key criterion of the FAIR data principles. Data held in a repository that is not easy to find is usually also not findable itself. Of course, other means of digital data storage and dissemination exist in Austria, but they are dispersed. This is not only a problem in archaeology but across all the humanities (Mayer $\underline{2019}$, 
142). Finding aids like the Austrian Public Database of Research Infrastructures hosted by the Austrian Federal Economic Chamber and the Federal Ministry for Digital and Economic Affairs or the project overview provided by Digital Humanities Austria aim to mitigate this dispersion.

Further systems, especially online databases, are mainly project-based or linked to museums, and can only be found in respective information pages. Examples include the 3D Kulturdatenbank with 3D scans of Roman objects and THANADOS, which contains information about burials. The latter provides export functions to allow for local working with the data. The ability to export data, especially in bulk, is something many online databases still lack.

In 2019, the BDA started a pilot project in cooperation with the state of Styria to map all areas of archaeological interest in a Geographic Information System. The BDA is planning to extend these efforts to the whole of Austria. The current status of these efforts is not clearly documented, but the states of Styria, Tirol, and Vienna can already be browsed. The BDA is also developing a monument information system that will include data, references, and geoinformation (Blesl et al. 2015).

\section{Available Repositories}

As described in the previous section, a few repositories for the storage of digital archaeological data already exist in Austria, and can easily be found via registries like OpenDOAR or re3data.org. They will now be examined in more detail, beginning with the oldest.

\subsection{GAMS}

The Geisteswissenschaftliches Asset Management System (GAMS, AMS for the Humanities) was established in 2003. It is hosted by the Zentrum für Informationsmodellierung - Austrian Centre for Digital Humanities of the University of Graz. It is a disciplinary service for the long-term preservation of general Arts and Humanities data. Data can only be included within the framework of a cooperation project. Metadata and some data types can be accessed via various machine-readable endpoints, including OAI-PMH. GAMS was awarded the CoreTrustSeal in 2019, where it indicated it has five staff members with an equivalent of 3.5 full-time positions (GAMS 2019, Requirement 5). The system currently has eight collections that can be categorised as archaeological. An example is the Onlineportal der archäologischen Sammlungen der Karl-Franzens-Universität Graz, described by Christidis et al. (2015).

\subsection{University of Vienna PHAIDRA}

PHAIDRA at the University of Vienna was established in 2008 as a repository for members of the university. The multidisciplinary service allows the self-deposit of data by university members. Machine access to metadata is provided via OAI-PMH. The staff consists of six members. Currently, 890 resources in the system can be associated with archaeology by searching for either 'archäologie' or 'archaeology'. The preparation and deposit process is described by Hagmann (2018) using excavation data from Molino San Vincenzo. 


\subsection{PHAIDRA @ FH St Pölten}

The underlying system of PHAIDRA, originally developed at the University of Vienna, is used for several other repositories, like PHAIDRA @ FH St Pölten hosted by the St Pölten University of Applied Sciences since 2014. Similar properties apply: it is multidisciplinary and university members can self-deposit. No machine-readable endpoint for metadata or data is documented. Only one resource, a thesis, is related to archaeology.

\subsection{ARCHE}

A Resource Centre for the HumanitiEs (ARCHE) was established in 2017 at the Austrian Centre for Digital Humanities and Cultural Heritage of the Austrian Academy of Sciences (ACDH-CH). It was designed for the long-term preservation of data from the Austrian arts and humanities community. Metadata and some data types can be accessed via various machine-readable endpoints, including OAI-PMH. ARCHE was awarded the CoreTrustSeal in 2018, where it stated that it has five staff members with an equivalent of 3.5 full-time positions (ARCHE 2018, Requirement 5). Five collections with a total of 15,026 resources can currently be categorised as archaeological. An example is Wares, Types and Fabrics: The Upper Egypt Contribution to Levantine Ceramics Project (LCP), which is further described by High-Steskal et al. (2017) and High-Steskal (2019).

\section{Summary and Outlook}

The low number of archaeological datasets in the available repositories, the dispersed nature of the datasets, and the missing incentives for depositing data indicate that archiving of digital archaeological research data in Austria is not treated as mandatory, or even considered common practice. In the last few years, a change has started: the FWF now enforces an Open Access policy for data that includes its long-term preservation and the Austrian government pursues a digitisation agenda with several initiatives, grants, and target agreements. Some institutions have set up dedicated working groups and the BDA has begun digitisation and is planning to open its finds report archive.

Still, many gaps exist that must be closed. This is addressed in general in Bauer et al. (2015) and Mayer (2019). Specifically, measures for archaeology could include Open Access publishing of The Fundberiche aus Österreich and a central registry or aggregation service for digital data sources would help to make data findable and visible for reuse. This service could act as a hub within the ARIADNE Portal, much like the Europeana Aggregators. A central repository, as Geser (2019) proposes, could also work but it would certainly require legal pressure.

While efforts to establish a research alliance between GAMS, University of Vienna PHAIDRA and ARCHE exist (Mayer 2019, 146), either the overall number of staff members or the number of digital archives must be increased significantly to be able to handle data from all federal, state, university, and museum actors introduced earlier. After all, one thing is certain: more digital data is coming. 
ARCHE 2018 Assessment Information for CoreTrustSeal 2017-

2019. https://www.coretrustseal.org/wp-content/uploads/2018/03/ARCHE.pdf [Last accessed: 12 March 2021].

Aspöck, E. 2019 'ARIADNE and ARIADNEplus in Austria' in F. Niccolucci and J. Richards (eds) The ARIADNE Impact, Budapest: Archaeolingua Foundation, 5162. http://doi.org/10.5281/zenodo.3476712

Bauer, B. and Ferus, A. 2018 'Österreichische Repositorien in OpenDOAR und re3data.org: Entwicklung und Status von Infrastrukturen für Green Open Access und Forschungsdaten', Mitteilungen der Vereinigung Österreichischer Bibliothekarinnen und Bibliothekare, 71(1), 70-86. https://www.doi.org/10.31263/voebm.v7111.2037

Bauer, B., Ferus, A., Gorraiz, J., Gründhammer, V., Gumpenberger, C., Maly, N., Mühlegger, J. M., Preza, J. L., Sánchez Solís, B., Schmidt, N. and Steineder, C. 2015 Forschende und ihre Daten. Ergebnisse einer österreichweiten Befragung - Report 2015. http://doi.org/10.5281/zenodo.32043

BDA Guidelines/Bundesdenkmalamt 2018 Richtlinien für archäologische Maßnahmen und Vorlagen/Guidelines for Archaeological

Interventions https://bda.gv.at/publikationen/standards-leitfaeden-richtlinien/richtlinienfuer-archaeologische-

massnahmen// https://bda.gv.at/fileadmin/Dokumente/bda.gv.at/Publikationen/Richtlinie n/Richtlinien/Guidelines2020 Download.pdf (English) [Last accessed: 12 March 2021].

Blesl, C., Gaisbauer, I. and Schön, D. 2015 'Reset and start - The reanalysis and new presentation of an old excavation in Vienna's historical and topographical core' in W. Börner and S. Uhlirz Proceedings of the 19th International Conference on Cultural Heritage and New Technologies 2014 (CHNT 19, 2014), Museen der Stadt Wien Stadtarchäologie, Vienna, Austria Nov. 3-5 2014. https://www.chnt.at/wpcontent/uploads/eBook CHNT19 Blesl etal.pdf [Last accessed: 12 March 2021].

Breibert, W. 2019 'Zum Wachstum verdammt. Vom Finden und Bewahren' in A. Laussegger and S. Sam (eds) Tätigkeitsbericht 2018 der Landessammlungen Niederösterreich und des Zentrums für Museale Sammlungswissenschaften, Krems: Veröffentlichungen aus den Landessammlungen Niederösterreich. 2629. https://www.donau-uni.ac.at/dam/jcr:6d15126e-d44d-4acc-bce5de01d2eea802/T\%C3\%A4tigkeitsbericht\%202018.pdf [Last accessed: 12 March 2021].

Christidis, M., Kargl, C. and Steiner, E. 2015 'Die archäologischen Sammlungen der Universität Graz auf dem Weg ins digitale Zeitalter', Forum Archaeologiae 75(VI). https://homepage.univie.ac.at/elisabeth.trinkl/forum/forum0615/for um75museum.pdf [Last accessed: 12 March 2021].

Digital Roadmap Austria 2016 Bundeskanzleramt und Bundesministerium für Wissenschaft, Forschung und Wirtschaft 2016 Digital Roadmap Austria. https://www.digitalroadmap.gv.at/fileadmin/downloads/digital road map brosch uere.pdf [Last accessed: 12 March 2021].

DMSG, Bundesgesetz betreffend den Schutz von Denkmalen wegen ihrer geschichtlichen, künstlerischen oder sonstigen kulturellen Bedeutung (Denkmalschutzgesetz - DMSG) / Federal Act on the Protection of Monuments Due to 
Their Historic, Artistic or Other Cultural Significance (Monument Protection Act - MPA), BGBI. Nr.

533/1923 https://www.ris.bka.gv.at/GeltendeFassung.wxe?Abfrage=Bundesnormen\&Ge setzesnummer=10009184 / https://www.ris.bka.gv.at/Dokumente/Erv/ERV 1923 533/E RV 1923 533.pdf (English) [Last accessed: 12 March 2021].

Faro Treaty Council of Europe Framework Convention on the Value of Cultural Heritage for Society (Faro Treaty) 2011, CETS

No.199 https://www.coe.int/en/web/conventions/full-list/-/conventions/treaty/199 [Last accessed: 12 March 2021].

Friesinger, H. and Titscher, S. (eds) 2004 Archäologie in Österreich, Vienna: Verlag der Österreichischen Akademie der Wissenschaften.

GAMS, 2019 Assessment Information for CoreTrustSeal 2017-

2019. https://www.coretrustseal.org/wp-content/uploads/2019/04/GAMS-

Geisteswissenschaftliches-Asset-Management-System.pdf [Last accessed: 12 March 2021].

Geser, G. 2019 'ARIADNEplus and community data repositories. Innovative solutions for sharing open archaeological data' in Abstracts of the 19th International Conference on Cultural Heritage and New Technologies 2019 (CHNT 24, 2019), Vienna, Austria Nov. 46 2019. https://www.chnt.at/wp-content/uploads/ARIADNEplus-and-community-datarepositories.pdf [Last accessed: 12 March 2021].

Hagmann, D. 2018 'Überlegungen zur Nutzung von PHAIDRA als Repositorium für digitale archäologische Daten', Mitteilungen der Vereinigung Österreichischer

Bibliothekarinnen und Bibliothekare 71(1), 53-

69. https://www.doi.org/10.31263/voebm.v71i1.1974

High-Steskal, N. 2019 Anleitung zur Archivierung von

Keramikdaten. http://doi.org/10.5281/zenodo.3385579

High-Steskal, N., Rembart, L., Schwaiger, H. and Ladstätter, S. 2017 Wares, Types and Fabrics. The Upper Egyptian Contribution to the

LCP. http://doi.org/10.5281/zenodo.3373303

Hofer, N. 2011 '50 Bände Fundberichte aus Österreich', Fundberichte aus Österreich 50, 13-16.

Horejs, B. (ed) 2018 OREA Annual Report

2018. https://doi.org/10.15661/OREA/annualreport/2018 [Last accessed: 12 March 2021].

Horejs, B. and OREA team (eds) 2016 OREA Annual Report

2015. https://www.oeaw.ac.at/fileadmin/Institute/OREA/pdf/Publikationen/OREA Annual Report 2015.pdf [Last accessed: 12 March 2021].

Karl, R. 2015 'Besser dem Zufall vertrauen oder strategisch auswählen?

Selektionsstrategien für archäologische Sammlungen', Archäologische

Informationen 38, 219-31. https://doi.org/10.11588/ai.2015.1 
Karl, R. and Möller, K. 2014 Discovering the Archaeologists of Austria 2012-14, Vienna: Historica-Verlag. https://www.discovering-

archaeologists.eu/national reports/2014/AT\%20DISCO\%202014\%20Austria\%20nationa \%20report\%20english\%20final.pdf [Last accessed: 12 March 2021].

Mayer, K. 2019 Digital Humanities in Österreich. Ergebnisse der Studie 'Exploratives Mapping', Wien. https://doi.org/10.22163/fteval.2020.473

ÖAI 2017 Wissenschaftlicher Jahresbericht des Österreichischen Archäologischen Instituts

2017. https://www.oeaw.ac.at/fileadmin/Institute/OEAl/PDF/Kommunikation/Jahresberich te/OeAl Jahresbericht 2017.pdf [Last accessed: 12 March 2021].

Peter, S. 2019 'A citizen's view on public archaeology and heritage in Austria', Internet Archaeology 51. https://doi.org/10.11141/ia.51.8

Valletta Treaty European Convention on the Protection of the Archaeological Heritage (Revised) (Valletta Treaty) 1995, ETS

No.143 https://www.coe.int/en/web/conventions/full-list/-/conventions/treaty/143 [Last accessed: 12 March 2021].

Volgger, C. 2020 Protokoll Runder Tisch Archäologie 13.2.2020, Wien: im Ahnensaal der

Hofburg. https://bda.gv.at/fileadmin/Dokumente/bda.gv.at/Archaeologie/2020/Protokoll Runder Tisch Archaeologie 2020.pdf [Last accessed: 12 March 2021]. 